Article

\title{
Enhancing Rice Production by Potassium Management: Recommended Reasonable Fertilization Strategies in Different Inherent Soil Productivity Levels for a Sustainable Rice Production System
}

\author{
Wenting Jiang ${ }^{1}$, Xiukang Wang ${ }^{1, *}$, Yingying Xing ${ }^{1}$, Xiaohu Liu ${ }^{2, *}$, Zhigang Cui ${ }^{2}$ and \\ Lihui Yang ${ }^{2}$ \\ 1 College of Life Science, Yan'an University, Yan'an, Shaanxi 716000, China; jiangwenting@yau.edu.cn (W.J.); \\ xingyingying@yau.edu.cn (Y.X.) \\ 2 College of Land and Environmental, Shenyang Agriculture University, Shenyang 110866, China; \\ 2018220391@stu.syau.edu.cn (Z.C.); 20131095@stu.syau.edu.cn (L.Y.) \\ * Correspondence: wangxiukang@yau.edu.cn (X.W.); liuxiaohumail@163.com (X.L.)
}

Received: 7 October 2019; Accepted: 13 November 2019; Published: 19 November 2019

\begin{abstract}
Enhancing agricultural productivity with the minimum possible cost to the environment is crucial for sustainable agriculture development. The effective management of $\mathrm{K}$ fertilizer would reduce the pollution risk of fertilizer residue. The data from the 29 experimental sites for rice in Liaoning province were used to determine the effect of different $\mathrm{K}$ fertilizer management in increasing yield, $\mathrm{K}$ uptake, and potassium fertilizer contribution rates $\left(\mathrm{FCR}_{\mathrm{K}}\right)$ for rice. The relationship among rice yield, biomass accumulation and plant $\mathrm{K}$ uptake, and recommended reasonable $\mathrm{K}$ fertilizer application rates in different inherent soil productivity levels were evaluated. The four treatments comprised no $\mathrm{K}$ fertilizer (K0), $\mathrm{K}$ fertilizer application of $60 \mathrm{~kg} \mathrm{ha}^{-1}$ (K60), $120 \mathrm{~kg} \mathrm{ha}^{-1}$ (K120), and $180 \mathrm{~kg} \mathrm{ha}^{-1}$ (K180). The K120 treatment showed a significant yield increase (16.59\%) compared to the $\mathrm{K} 0$ treatment in this study. The average K uptake of grain in the K60, K120 and K180 treatments was $23.1,24.8$ and $24.9 \mathrm{~kg} \mathrm{ha}^{-1}$, which was significantly higher by $12.67 \%, 20.77 \%$, and $21.48 \%$ compared to the $\mathrm{K} 0$ treatment. The average $\mathrm{K}$ uptake of grain, straw and plant was highest in $\mathrm{K} 180$ $\left(134.8 \mathrm{~kg} \mathrm{ha}^{-1}\right)$, followed by the K120 and K60. Additionally, the correlation between grain yield, biomass accumulation (y) and plant $\mathrm{K}$ uptake $(\mathrm{x})$ showed a significant positive polynomial function. The equation was $y=-0.406 x^{2}+110.43 x+639.3$ and $y=-0.237 x^{2}+135.3 x+3796.2$, respectively. The FCR $\mathrm{K}_{\mathrm{K}}$ followed the sequence as $\mathrm{K} 180<\mathrm{K} 60<\mathrm{K} 120$. Furthermore, the recommended K application rates in the 29 experimental sites were ranged from 92.8 to $134.5 \mathrm{~kg} \mathrm{ha}^{-1}$, and the corresponding theoretical yield of recommended $\mathrm{K}$ rate were ranged from 7371.5 to 11144.5 , and with an average of $9297.5 \mathrm{~kg} \mathrm{ha}^{-1}$. Remarkably, the average recommended $\mathrm{K}$ rate in the four inherent soil productivity levels was 116.1, 111.2, 112.2 and $111.7 \mathrm{~kg} \mathrm{ha}^{-1}$ and the corresponding average theoretical yield was $9966.1 \mathrm{~kg} \mathrm{ha}^{-1}, 10158.8 \mathrm{~kg} \mathrm{ha}^{-1}, 8373.2 \mathrm{~kg} \mathrm{ha}^{-1}$ and $8881.9 \mathrm{~kg} \mathrm{ha}^{-1}$. The results of this study suggest that different inherent soil productivity levels have different $\mathrm{K}$ application rates and yield performance. This result somewhat strengthens the finding of this study that moderate K application is conducive to effectively improving the yield and to the enhancement of agricultural productivity, which is conducive to the sustainable environment.
\end{abstract}

Keywords: Oryza sativa L.; production; fertilizer contribution rates; sustainability; recommend fertilization 


\section{Introduction}

Rice (Oryza sativa L.) is one of the most important staple food crops, providing more than approximately $21 \%$ of the calorific intake for the global population [1,2]. Particularly in China, rice is extensively cultivated and forms the primary food crop for more than $60 \%$ of the population $[3,4]$. To satisfy the demands on food due to both population growth and diet diversity, production improvement is an urgent issue. Rice yield is predicted to double by 2030 [5].

Maintaining yield has accordingly become one of the vital targets in many countries over the past several decades. However, it is difficult to extend the arable area conductive to rice production because appropriate planting land has already been occupied by urban construction $[6,7]$. Further improvements in rice production must be achieved by many factors, including rice management techniques, site-specific fertilizer application [8], irrigation [9], and varieties. Although some of these agronomic techniques, innovations, or genetic variety improvements achieved the above purposes, fertilizer inputs could even further significantly increase production [5]. Although rice yield in China has presented dramatic growth in the last fifty years, excessive or insufficient fertilizer input has been one of the key problems confronting rice production $[10,11]$. A particular example is imbalanced fertilization, which has caused low fertilizer use efficiency and negative environmental problems, such as soil acidification [12,13], water eutrophication [14], and greenhouse gas emissions [15]. To maintain yield while preventing environmental damage, it is necessary to ensure the application of balanced fertilizer.

Potassium, as one of the most major macronutrients, is involved in a series of plant physiological and biochemical processes, the driving of plant development, enhancement of defense, stomatal regulation and signal transduction, and is, therefore, vital for producing high-yield and high-quality rice $[16,17]$. Although the earth's crust has enough potassium, it is extremely difficult to obtain adequate $\mathrm{K}$ immediately from the soil [18]. Therefore, $\mathrm{K}$ fertilizer is the primary way to solving $\mathrm{K}$ deficiency in plants or soil. However, nitrogen $(\mathrm{N})$ and phosphorus $(\mathrm{P})$ fertilizers have received more attention compared to $\mathrm{K}$ fertilizer [19], because farmers often deem that $\mathrm{N}$ and $\mathrm{P}$ fertilizer increase yield more rapidly, and they, therefore, tend to neglect the economic value of $K$ fertilizers $[20,21]$. Numerous studies have demonstrated that negative soil $\mathrm{K}$ status is widespread across some crop-producing regions in China due to a lack of sufficient nutrient recycling [22].

In view of the current situation, better $\mathrm{K}$ fertilizer management is one of the crucial factors that could facilitate rice production toward sustainable agricultural development, such as with $\mathrm{K}$ fertilizer recommendation. To date, most recommendation dosages have been based on small-scale field experiments, and few studies have focused on how these fertilizer recommendations can guide large-scale regional rice planting, especially in the different inherent soil productivity levels. To the best of our knowledge, no one has reported on the quantitative effects of these fertilizer recommendations on rice yield or their use efficiency at the provincial level, especially in the Liaoning province of China. Therefore, the objectives of this work were to (i) quantify the regional levels effect of these $\mathrm{K}$ fertilizer application on increasing yield, plant $\mathrm{K}$ uptake, and potassium contribute rate $\left(F C R_{K}\right)$. (ii) Evaluate the correlation among grain yield, biomass accumulation and plant $\mathrm{K}$ uptake across 29 experiment sites; (iii) recommend K application rates in different inherent soil productivity levels.

\section{Materials and Methods}

\subsection{Data Source and Site Description}

In this study, we focused on field experiments with multiple experimental sites because farming impacts on crop production were stable and credible only at 5 experimental sites. Thus, the data were obtained from the field experiments performed at 29 experimental sites in the main rice producing region of Liaoning province in during the period 2007-2012.

In Liaoning province, 29 field sites were located in the latitude range $38^{\circ} 43^{\prime} \mathrm{N}-43^{\circ} 26^{\prime} \mathrm{N}$ and the longitude range $118^{\circ} 53^{\prime} \mathrm{E}-125^{\circ} 46^{\prime} \mathrm{E}$, China (Figure 1). Liaoning province has become one of the major 
rice-producing regions in China, with 2691,980 of hectares planted in 2017. The region is characterized by a temperature zone with a continental monsoon climate. In the rice growing season (early-June to mid-October), the average annual temperature of $21.3{ }^{\circ} \mathrm{C}$ means that there is monthly sunshine of $218 \mathrm{~h}$, and the annual average precipitation is $546.1 \mathrm{~mm}$.

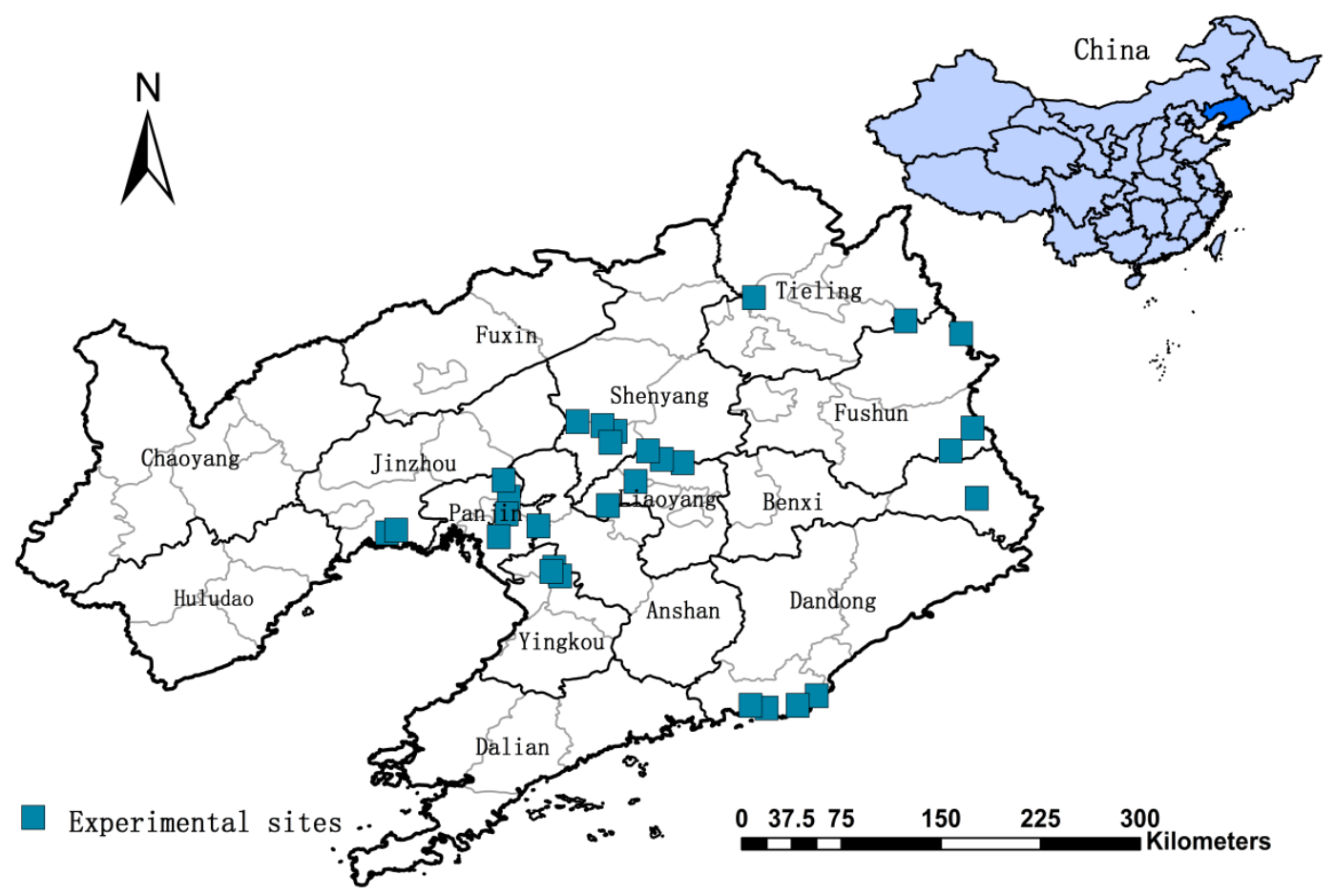

Figure 1. Distribution of the 29 experimental sites for rice in Liaoning province, China.

The soil type at all of the experimental sites was classified as typic Hapli-Stagnic Anthrosols (USDA soil system). The soil samples from the plow layer $(0-20 \mathrm{~cm})$ prior to the experiment had the following characteristics: soil $\mathrm{pH}$ (using 1:2.5 soil: water suspension) 5.7 (5.2-6.7), soil organic carbon (SOC) $10.3 \mathrm{~g} \mathrm{~kg}^{-1}$ (5.9-16.8 $\left.\mathrm{g} \mathrm{kg}^{-1}\right)$, total nitrogen (TN) $0.78 \mathrm{~g} \mathrm{~kg}^{-1}\left(0.54-1.34 \mathrm{~g} \mathrm{~kg}^{-1}\right)$, alkaline hydrolyze nitrogen (AN) $103.14 \mathrm{mg} \mathrm{kg}^{-1}$ (48.17-192 $\mathrm{mg} \mathrm{kg}^{-1}$ ); available phosphorus $12.85 \mathrm{mg} \mathrm{kg}^{-1}$ (5.56-31.82 $\mathrm{mg} \mathrm{kg}^{-1}$ ) and available potassium $110.5 \mathrm{mg} \mathrm{kg}^{-1}$ (79.4-141.54 $\left.\mathrm{mg} \mathrm{kg}^{-1}\right)$.

\subsection{Experimental Design and Management}

Data were obtained from the 29 field experiments conducted by the Project of Soil Testing and Fertilization Recommendation, and four treatments were chosen from a total of 14 fertilization treatments at each site. The four treatments comprised: no $\mathrm{K}$ fertilizer $(\mathrm{K} 0), \mathrm{K}$ fertilizer application of $60 \mathrm{~kg} \mathrm{ha}^{-1}$ (K60), $120 \mathrm{~kg} \mathrm{ha}^{-1}$ (K120), and $180 \mathrm{~kg} \mathrm{ha}^{-1}$ (K180). The annual amount of $\mathrm{N}$ and $\mathrm{P}$ fertilizer application rates were kept identical for each treatment: $195 \mathrm{~kg} \mathrm{~N} \mathrm{ha}^{-1}$ and $90 \mathrm{~kg} \mathrm{P} \mathrm{ha}^{-1}$. The experimental design was laid out in a completely randomized block with three replications. Nitrogen fertilizer was applied three times: approximately 50\% nitrogen (as urea), all P (as calcium superphosphate) and $\mathrm{K}$ fertilizer (as potassium chloride). Before rice sowing, basal fertilizers and $25 \%$ nitrogen fertilizers were applied at the jointing stage, and the remaining $25 \%$ nitrogen fertilizer was applied at the booting stage. Plant density was according to the recommendation of a local agricultural extension agency. All sites were managed in accordance with local farming practices. The spraying of pesticides, fungicides, and herbicides was managed during the crop growing season by depending upon local traditional farming practices. 


\subsection{Measurements}

The main recorded phenological stages were based on the plant growth characteristics for each field plot. The grain yield was harvested manually from a quadrat area of $1 \times 1 \mathrm{~m}^{2}$ in the middle rows of each field during the harvest season. The collected aboveground plant materials were separated into grain and straw, before being dried, threshed, and oven-dried at $105{ }^{\circ} \mathrm{C}$ for $30 \mathrm{~min}$ and then at $75{ }^{\circ} \mathrm{C}$ until the constant weight was recorded with a uniform moisture content of $13.5 \%$. The plant materials were ground to pass through a $0.5 \mathrm{~mm}$ mesh sieve and digested with $\mathrm{H}_{2} \mathrm{SO}_{4}$ and $\mathrm{H}_{2} \mathrm{O}_{2}$. The total $\mathrm{K}$ concentration of the digested samples was measured using the flame spectrophotometer method.

\subsection{Caculation}

Fertilizer contribution rates for $\mathrm{K}\left(\mathrm{FCR}_{\mathrm{K}}\right)$ under the varying $\mathrm{K}$ fertilization treatment was calculated as follows:

$$
F C R_{K}=\frac{\text { Grain yield with } \mathrm{K} \text { fertilization }- \text { Grain yield with no } \mathrm{K} \text { fertilization }}{\text { Grain yield with } \mathrm{K} \text { fertilization }}
$$

\subsection{Fertilizer Recommendation in Inherent Soil Productivity Levels}

The flow diagram of this study (based on the quadratic model) is shown in Figure 2. The selected quadratic models were used for $\mathrm{K}$ fertilizer recommendation, particularly in the different inherent soil productivity levels (L1, L2, L3 and L4). The inherent soil productivity levels were in accordance with the relationship between rice yields in the case of no $\mathrm{K}$ application and rice yields in the case of $\mathrm{K}$ application at a rate of $120 \mathrm{~kg} \mathrm{ha}^{-1}$, and divided into four inherent soil productivity levels.

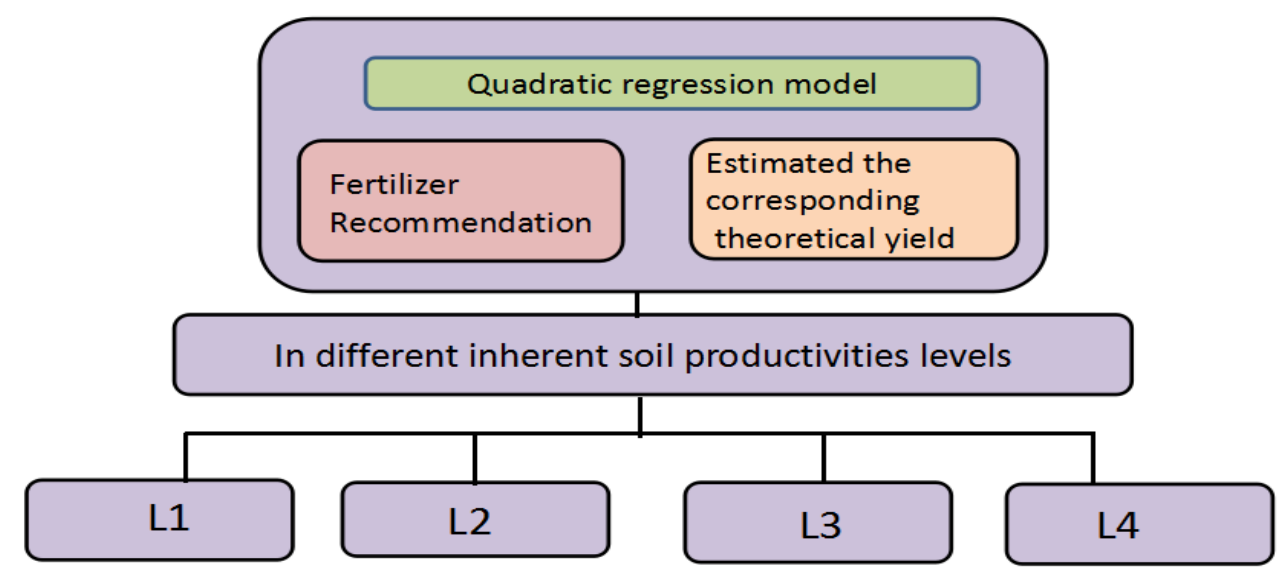

Figure 2. The diagram of fertilizer recommendation in inherent soil productivity levels.

Fertilizer Recommendation Used by the Quadratic Regression Model

In this study, the quadratic regression model was used to establish the relationship between grain yield (y) and fertilizer application rates ( $\mathrm{x}$ ), and also, to calculate the optimal fertilizer application rates.

$$
\mathrm{Y}=\mathrm{a}+\mathrm{bx}+\mathrm{cx^{2 }}
$$

where $\mathrm{Y}$ represents the grain yield $(\mathrm{kg} / \mathrm{ha})$, $\mathrm{x}$ represents the fertilizer application, $\mathrm{a}$ is the basis grain yield $(\mathrm{kg} / \mathrm{ha}), \mathrm{b}$ is the coefficient, and $\mathrm{c}$ is quadratic regression coefficient.

\subsection{Statistical Analysis}

The SPSS 16 (SPSS, Inc. Chicago, IL, USA) statistics software was used to perform descriptive statistical analysis. Descriptive statistical analyses were performed to evaluate the mean, variability and standard deviation (SD) of the parameters. The difference of increasing yield, $\mathrm{K}$ uptake, and 
potassium fertilizer contribution rates $\left(\mathrm{FCR}_{\mathrm{K}}\right)$ between all treatments was analyzed using analysis of variance (ANOVA) with the least significant difference (LSD) test at the $5 \%$ probability level $(\mathrm{P} \leq 0.05)$. The figures were made using Origin pro 2018 software packages.

\section{Results and Discussion}

\subsection{Increasing Yield to Applied K Levels}

Across the 29 experimental sites, there was significant influence by $\mathrm{K}$ fertilization treatments on the rice grain yield (Figure 3). The average yield with K0 treatment was $7155.5 \mathrm{~kg} \mathrm{ha}^{-1}$, and ranged from 4050 to $9111.3 \mathrm{~kg} \mathrm{ha}^{-1}$, respectively (Figure 3). The highest yield consistently achieved in the K120 treatment during the experimental period (with an average of $8342.6 \mathrm{~kg} \mathrm{ha}^{-1}$ ) ranged from 6305 to $10021.4 \mathrm{~kg} \mathrm{ha}^{-1}$, which was $522-2303.8 \mathrm{~kg} \mathrm{ha}^{-1}$ higher than that obtained with the $\mathrm{K} 0$ treatments. (Figure 3). In contrast, the lower yield increase in both years was markedly observed in the K60 and $\mathrm{K} 180$ treatment, which increased the grain yield by an average of $617.9 \mathrm{~kg} \mathrm{ha}^{-1}$ and $557.2 \mathrm{~kg} \mathrm{ha}^{-1}$, relative to K0, respectively (Figure 3). Overall, the average yield increase for rice of the K60, K120, and K180 treatments, in both years, was higher by $8.64 \%, 16.59 \%$ and $7.79 \%$ compared to the K0 treatment. This indicated that a balanced K application of $120 \mathrm{~kg} \mathrm{ha}^{-1}$ (K120) was preponderant. The impact of K fertilizers on the increasing yield followed the sequence K120 > K60 $>$ K180 > K0. Zhang et al. [23] also reported similar results, when they conducted a case study on rice in the Hubei province of China, and found that $21.91 \%$ of the highest increasing yield was attributed to $120 \mathrm{~kg} \mathrm{~K}_{2} \mathrm{O} \mathrm{ha}^{-1}$, and followed by 60 and $180 \mathrm{~kg} \mathrm{~K}_{2} \mathrm{O} \mathrm{ha}{ }^{-1}$.

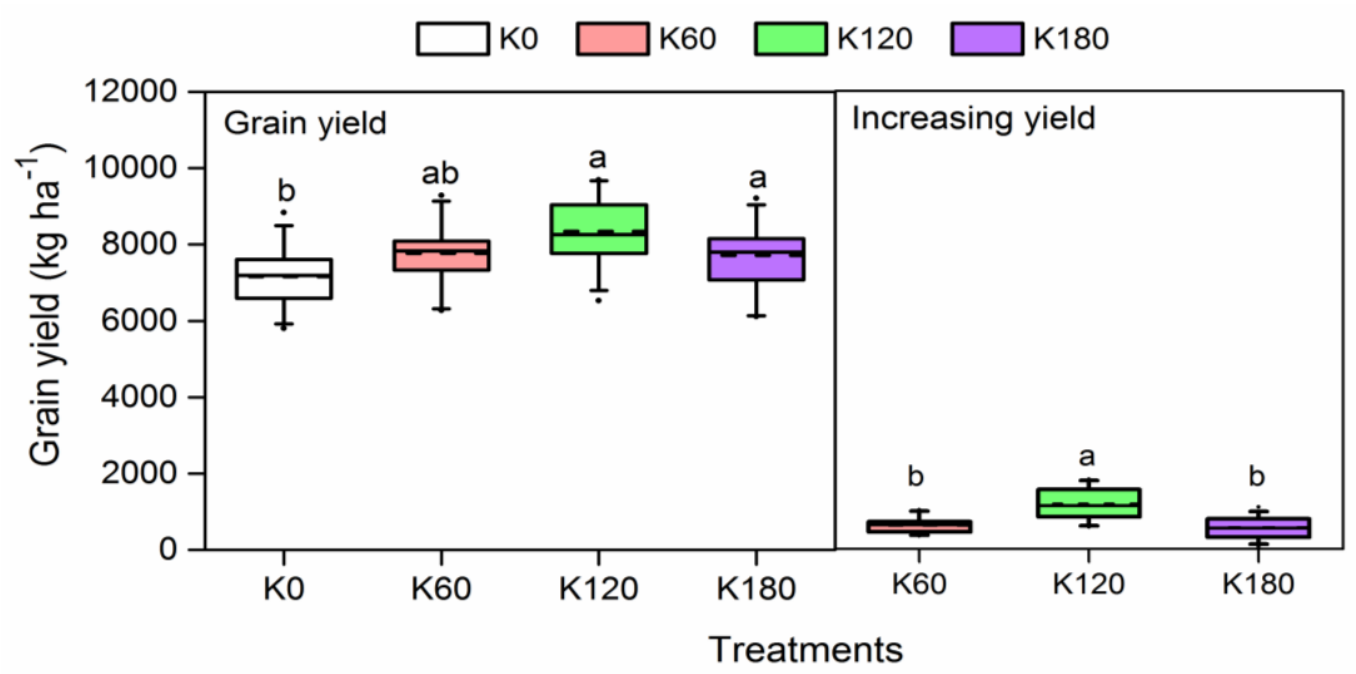

Figure 3. Grain yield and increasing yield in the applied four K levels across the 29 experiment sites. Solid and dotted lines indicate median and mean values, respectively; box boundaries indicate the upper and lower quartiles; whisker caps indicate 90th and 10th percentiles; different lowercase letters indicate a significant difference $(\mathrm{p}<0.01)$ among different treatments.

In our study, the average grain yield in all $\mathrm{K}$ application treatments was considerably higher than the average yield in worldwide $\left(4294 \mathrm{~kg} \mathrm{ha}^{-1}\right)$ and China $\left(6498 \mathrm{~kg} \mathrm{ha}^{-1}\right)$ during the period 2006-2011 [24]. The variation in grain increase observed in our research was large because of the differences in the effective use of K fertilizers. Furthermore, the average rice yield in the K120 treatment in our study was increased by $9.77 \%$ compared with that observed by $\mathrm{Xu}$ et al. [25] in Northeast China (7600 kg ha-1) during 2000-2011, which indicates that $120 \mathrm{~kg} \mathrm{ha}^{-1}$ rate of K application could improve grain yield to a greater extent than both other rates of $\mathrm{K}$ application and farmers' traditional fertilization practices. 


\subsection{Potassium Uptake of the Plant, Straw and Grain in Different K Application Levels}

The plant $\mathrm{N}$ uptake in different aerial parts of rice, was influenced by $\mathrm{K}$ fertilizer application (Figure 4). The average K uptake of grain in the K60, K120 and K180 treatments was 23.1, 24.8 and $24.9 \mathrm{~kg} \mathrm{ha}^{-1}$, which was higher by $12.67 \%, 20.77 \%$ and $21.48 \%$ compared to K0 (Figure 4c). Moreover, the straw $\mathrm{K}$ uptake in the K180 treatment was still higher at $40.55 \%, 22.21 \%$ and $5.86 \%$, which was higher than those in the K0, K60 and K120 treatments (Figure 4b).

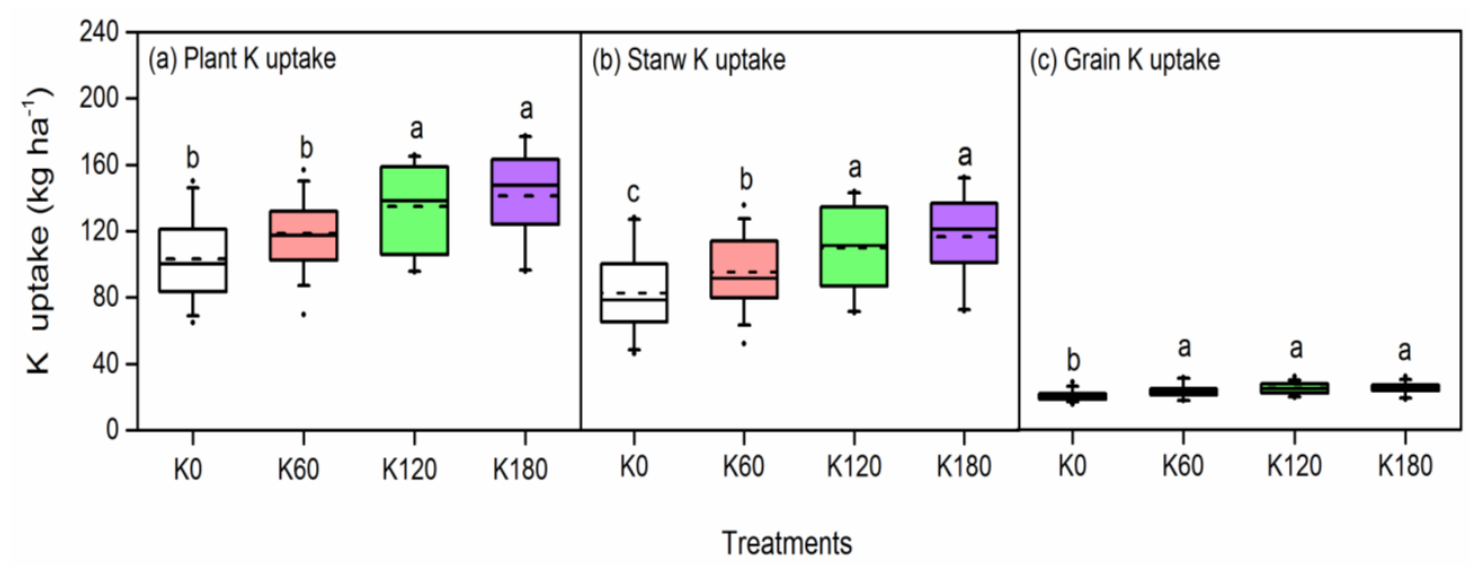

Figure 4. Plant K uptake (a), straw K uptake (b), and grain K uptake (c) in four K fertilizer application levels across the 29 experiment sites.

The total plant $\mathrm{K}$ uptake of rice in all $\mathrm{K}$ fertilization treatments was significantly increased by $14.5 \%-36.7 \%$ compared with the K0 treatment (Figure 4a). The lowest plant $\mathrm{K}$ uptake during the experimental period was recorded for the $\mathrm{K} 0$ treatment, where total plant $\mathrm{K}$ uptake ranged from 59.1 to $165.5 \mathrm{~kg} \mathrm{ha}^{-1}$, with an average of $105.3 \mathrm{~kg} \mathrm{ha}^{-1}$. The average plant $\mathrm{K}$ uptake was $118.4 \mathrm{~kg} \mathrm{ha}^{-1}$ in $\mathrm{K} 60$, $134.8 \mathrm{~kg} \mathrm{ha}^{-1}$ in K120 and $141.4 \mathrm{~kg} \mathrm{ha}^{-1}$ in K180 (Figure 4a). Therefore, the highest plant K uptake was observed in K180 treatment, followed by the K120 and K60. The same results were also observed in straw and grain $\mathrm{K}$ uptake. These results are in accordance with previous studies reported by Liao et al. [26] for rice, Qiu et al. [27] for maize, and Chen et al. [28] for cotton, who reported that plant K uptake increased with a rising $\mathrm{K}$ application rate.

\subsection{Correlation Among Biomass Accumulation, Grain Yield, and Plant K Uptake}

The correlation between grain yield (y) and plant $\mathrm{K}$ uptake $(\mathrm{x})$ showed a significant positive polynomial function $(P<0.05)$, the equation was $y=-0.406 x^{2}+110.43 x+639.3$, and $R^{2}$ was 0.226 (Figure 5). The results show that the increased plant potassium absorption contributed to increased grain yield. About $22.6 \%$ of the variation in the aboveground $\mathrm{K}$ uptake is explained by grain yield (Figure 5). Similarly, there was found to be a remarkable correlation between biomass accumulation and plant $\mathrm{K}$ uptake, whereas the biomass accumulation showed significant polynomial function with $\mathrm{K}$ uptake, for which the equation is $\mathrm{y}=-0.237 \mathrm{x}^{2}+135.3 \mathrm{x}+3796.2$. This indicates that about $58.3 \%$ of the variation in the aboveground $\mathrm{K}$ uptake is explained by the biomass accumulation (Figure 5). This result shows that the grain yield and biomass partly depended upon the amount of plant $\mathrm{K}$ uptake. 


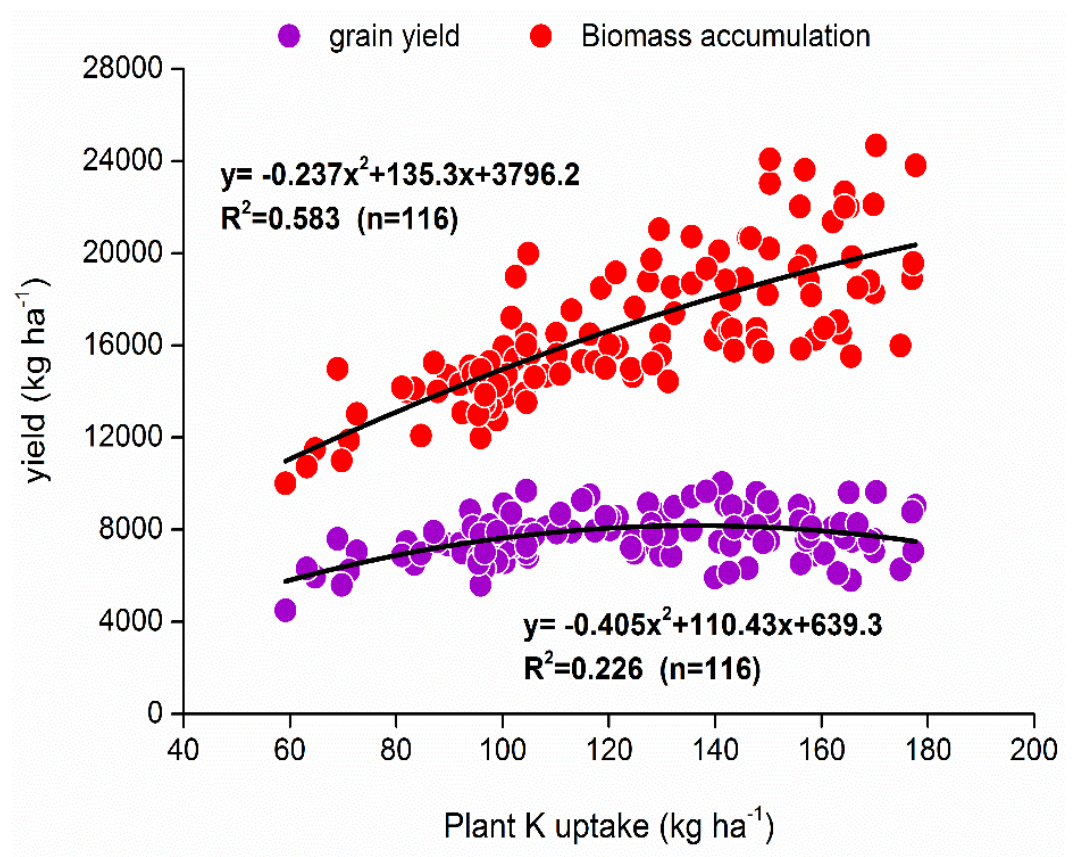

Figure 5. The correlation between the grain yield (y), biomass accumulation and plant $\mathrm{K}$ uptake (x) across the 29 experiment sites.

\subsection{Potassium Contribution Rates $\left(F C R_{K}\right)$}

There were differences in the potassium fertilizer contribution rates among different $\mathrm{K}$ application levels. Table 1 shows the values for the parameters of $\mathrm{FCR}_{\mathrm{K}}$. This is the amount FCRK increased as a function of the K level from K0 to K180. During the period 2007-2012, the average $\mathrm{FCR}_{\mathrm{K}}$ was $8.11 \%$ at $\mathrm{K} 60,14.29 \%$ at $\mathrm{K} 120$, and $7.30 \%$ at $\mathrm{K} 180$ (Table 1). The highest average $\mathrm{FCR}_{\mathrm{K}}$ in the four $\mathrm{K}$ application levels occurred in K120 treatment, followed by K60 and K180. Chuan et al. [29] also showed that the average $\mathrm{K}$ contribution rate for wheat was $11.3 \%$ during 2000-2011 in China. Therefore, these results show that $\mathrm{K}$ fertilization under the $\mathrm{K} 120$ treatment contributes more grain and nutrient for rice production.

Table 1. Effect of the $\mathrm{K}$ application treatment on the potassium fertilizer contribution rates $\left(\mathrm{FCR}_{\mathrm{K}}\right)$ in rice across the 29 experimental sites in Northeast China.

\begin{tabular}{ccccccc}
\hline \multirow{2}{*}{ Treatments } & \multicolumn{5}{c}{ Potassium Fertilizer Contribution Rates (\%) } \\
\cline { 2 - 6 } & Mean & SD & Min & $\mathbf{2 5 \%}^{\mathbf{b}}$ & $\mathbf{7 5 \%}^{\mathbf{b}}$ & Max \\
\hline K60 & 8.11 & 3.29 & 4.07 & 5.48 & 9.50 & 19.55 \\
K120 & 14.29 & 5.46 & 6.40 & 9.33 & 18.04 & 28.55 \\
K180 & 7.30 & 4.48 & 0.48 & 3.70 & 10.38 & 19.70 \\
\hline \multicolumn{7}{c}{ a SD = standard deviation. ${ }^{\mathrm{b}} \mathrm{Q}=$ quartile. }
\end{tabular}

In conclusion, scientific $\mathrm{K}$ management is crucial for improving rice productivity, $\mathrm{K}$ contribution rate, and environmental sustainability. This study reveals that rice yields were significantly higher in the $120 \mathrm{~kg} \mathrm{ha}^{-1} \mathrm{~K}$ application rates. The lower contribution rate values indicate that reasonable $\mathrm{K}$ fertilizer application is needed to prevent environmental damage and improve potassium use efficiency.

\subsection{Fertilizer Recommendation of Rice for Sustainability Agriculture}

Use of the quadratic regression model to fit the relationship between the grain yield and $\mathrm{K}$ fertilizer application rates for 29 experimental sites is shown in Figure 4. Additionally, the model equations for all sites were established (Table 2). Average regression coefficients aK, bK and cK were 7098, 19.33 and 
-0.087 (Figure 6), and ranged from 4454.5 to $9057.5,10.38$ to 30.45 , and -0.134 to -0.042 , respectively (Table 2). Thus, the average quadratic regression model $\mathrm{Y}=7098+19.33 \mathrm{~K}-0.087 \mathrm{~K}^{2}$ was obtained (Figure 6). The fitting relation $\left(R^{2}\right)$ had a good correlation, and most of $R^{2}$ was above 0.8 , and ranged from 0.589 to 0.991 (Table 2). Therefore, the recommended $\mathrm{K}$ application rates ranged from 92.8 to $134.5 \mathrm{~kg} \mathrm{ha}^{-1}$, with an average of $112 \mathrm{~kg} \mathrm{ha}^{-1}$. Furthermore, the corresponding theoretical yields of the recommended $\mathrm{K}$ rate ranged from 7371.5 to 11144.5 , with an average of $9297.5 \mathrm{~kg} \mathrm{ha}^{-1}$ (Figure 7).

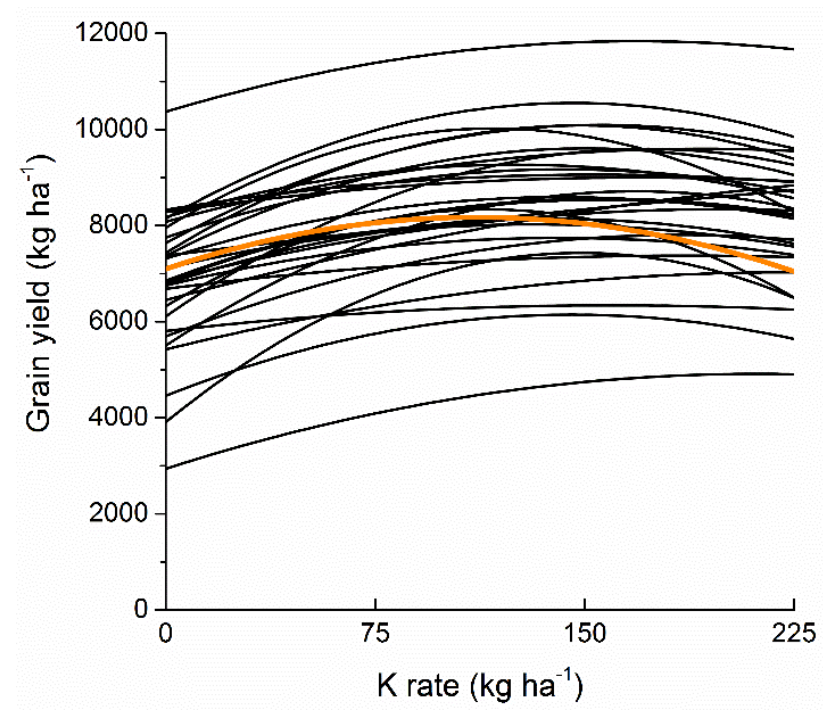

Figure 6. The potassium response curves estimated for the quadratic equation model to fit the relationship between yield and $\mathrm{K}$ fertilizer application rates for rice for the 29 sites. The orange curve is the average quadratic regression model.
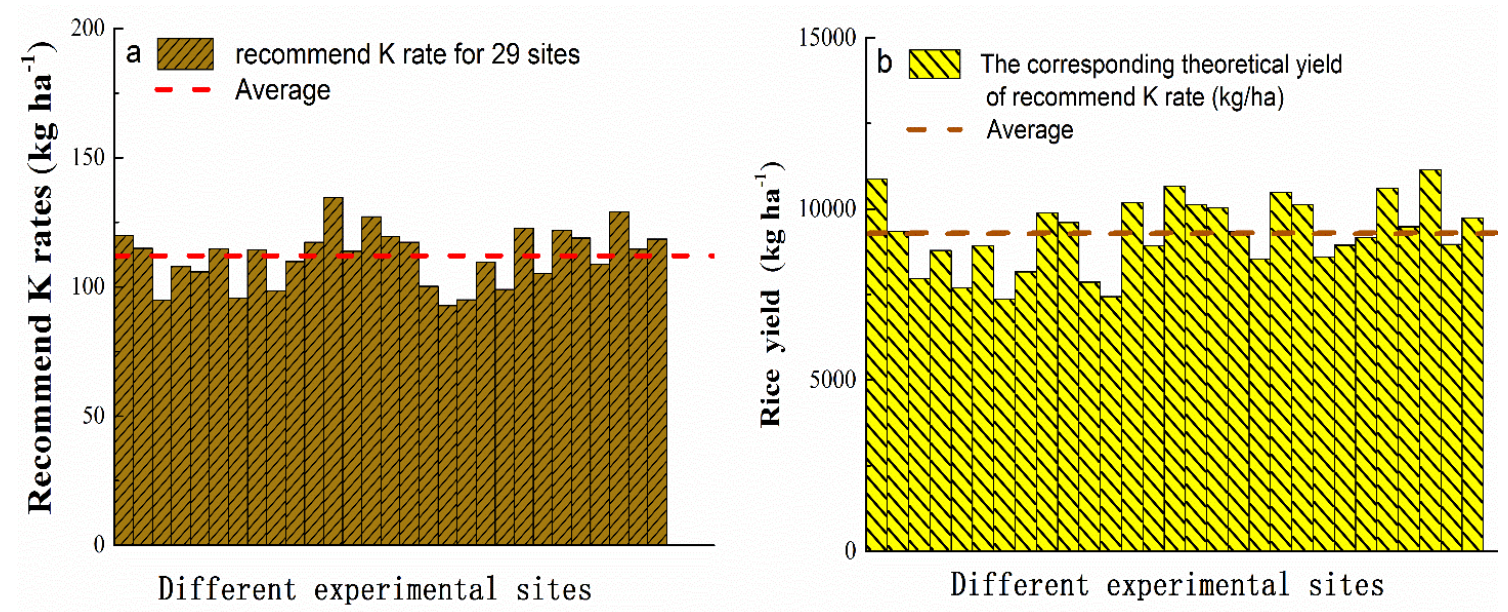

Figure 7. Recommended $\mathrm{K}$ application rates and the corresponding theoretical yield across the 29 experimental sites for rice. The dashed red and brown lines in the figure indicate mean values, respectively. 
Table 2. The quadratic equation models describing the relationship between yield and fertilizer application for rice at different experimental sites.

\begin{tabular}{|c|c|c|c|c|c|}
\hline Experimental Sites & $Y=a+b x+c x^{2}$ & $\mathbf{R}^{2}$ & Experimental Sites & $Y=a+b x+c x^{2}$ & $\mathbf{R}^{2}$ \\
\hline Site 1 & $y=8052.8+23.48 x-0.098 x 2$ & $0.951 * *$ & Site 16 & $y=7228.8+24.62 x-0.105 x^{2}$ & $0.839 * *$ \\
\hline Site 2 & $y=6757.7+22.51 x-0.0098 x 2$ & $0.908^{* *}$ & Site 17 & $y=8824.5+12.02 x-0.06 x^{2}$ & $0.984^{* *}$ \\
\hline Site 3 & $y=6966.5+10.62 x-0.056 \times 2$ & $0.938 * *$ & Site 18 & $y=8003.4+14.47 x-0.078 x^{2}$ & $0.978 * *$ \\
\hline Site 4 & $y=7586.8+10.38 x-0.045 x 2$ & $0.959 * *$ & Site 19 & $y=7059.6+15.58 x-0.082 x^{2}$ & $0.998^{* *}$ \\
\hline Site 5 & $y=5752.8+18.61 x-0.088 x 2$ & $0.794 * *$ & Site 20 & $y=8202.4+20.81 x-0.095 x^{2}$ & $0.674 * *$ \\
\hline Site 6 & $y=7366.7+13.53 x-0.059 x 2$ & $0.991 * *$ & Site 21 & $y=7896.2+22.56 x-0.114 x^{2}$ & $0.983 * *$ \\
\hline Site 7 & $y=5941.4+14.93 x-0.078 x 2$ & $0.746^{* *}$ & Site 22 & $y=6247+19.15 x-0.078 x^{2}$ & $0.757^{* *}$ \\
\hline Site 8 & $y=6512.1+14.4 x-0.063 \times 2$ & $0.754 * *$ & Site 23 & $y=7468.4+13.89 x-0.057 x^{2}$ & $0.988 * *$ \\
\hline Site 9 & $y=7287+26.37 x-0.134 x 2$ & $0.603 * *$ & Site 24 & $y=8455.5+18.06 x-0.076 x^{2}$ & $0.589 * *$ \\
\hline Site 10 & $y=6454.5+28.75 x-0.131 x 2$ & $0.943 * *$ & Site 25 & $y=8455.5+18.06 x-0.076 x^{2}$ & $0.943 * *$ \\
\hline Site 11 & $y=4454.5+29.07 x-0.124 \times 2$ & $0.969 * *$ & Site 26 & $y=7231.3+20.65 x-0.095 x^{2}$ & $0.92 * *$ \\
\hline Site 12 & $y=5918+11.3 x-0.042 \times 2$ & $0.908^{* *}$ & Site 27 & $y=7214.6+30.44 x-0.118 x^{2}$ & 0.786 ** \\
\hline Site 13 & $y=6823.1+29.59 x-0.13 x 2$ & $0.939 * *$ & Site 28 & $y=6157.3+24.52-0.107 x^{2}$ & $0.901 * *$ \\
\hline Site 14 & $y=6979.8+15.25 x-0.06 x^{2}$ & 0.911 ** & Site 29 & $y=6874.6+24.16 x-0.102 x^{2}$ & $0.874^{* *}$ \\
\hline Site 15 & $y=9057.4+13.38 x-0.056 x^{2}$ & $0.862 * *$ & & & \\
\hline
\end{tabular}

The " $y$ " is the grain yield, and the " $x$ " means $K$ application rate. ** indicates significance at $\mathrm{P}<0.01$. 


\subsection{Recommended K Rates in Different Inherent Soil Productivity and Crop Management Styles}

In accordance with previous studies, we established the relationship between the rice yield rate without $\mathrm{K}$ application and rice yields with a $\mathrm{K}$ application rate of $120 \mathrm{~kg} \mathrm{ha}^{-1}$, and divided the data from the 29 experimental sites into four inherent soil productivity levels (Figure 8): L1, the group with low yield in a K application of $0 \mathrm{~kg} \mathrm{~K}_{2} \mathrm{O} \mathrm{ha}{ }^{-1}$ and high yield in $120 \mathrm{~kg} \mathrm{~K}_{2} \mathrm{O} \mathrm{ha}^{-1}$; L2, high yield in both $\mathrm{K}$ applications of 0 and $120 \mathrm{~kg} \mathrm{~K}_{2} \mathrm{O} \mathrm{ha}^{-1}$; L3, low yield in both $\mathrm{K}$ applications of 0 and $120 \mathrm{~kg}$ $\mathrm{K}_{2} \mathrm{O} \mathrm{ha}^{-1}$; and $\mathrm{L} 4$, high yield in $\mathrm{K}$ applications of $0 \mathrm{~kg} \mathrm{~K}_{2} \mathrm{O} \mathrm{ha}^{-1}$ and low yield in $120 \mathrm{~kg} \mathrm{~K}_{2} \mathrm{O} \mathrm{ha}{ }^{-1}$. Here, the 29 experimental sites were distributed in four inherent soil productivity levels: L1( $n=2)$, L2 $(\mathrm{n}=12)$, L3 $(\mathrm{n}=12)$, and L4 $(\mathrm{n}=2)$ (Figure 8). The average recommended $\mathrm{K}$ application rates in levels of L1, L2, L3, and L4 were 116.1, 111.2, 112.2, and $111.7 \mathrm{~kg} \mathrm{ha}^{-1}$, and ranged from 113.8 to $118.5 \mathrm{~kg} \mathrm{ha}^{-1}$, 92.8 to $129.0 \mathrm{~kg} \mathrm{ha}^{-1}, 94.8$ to $134.5 \mathrm{~kg} \mathrm{ha}^{-1}$ and 105.1 to $115.4 \mathrm{~kg} \mathrm{ha}^{-1}$ (Table 3). Therefore, the average corresponding theoretical yield was highest in L2 (10158.8 kg ha-1), followed by L1 $\left(9966.1 \mathrm{~kg} \mathrm{ha}^{-1}\right)$, L4 (8881.9 $\mathrm{kg} \mathrm{ha}^{-1}$ ) and L3 (8373.2 $\mathrm{kg} \mathrm{ha}^{-1}$ ) (Table 3). We conclude that these results can be used to provide valuable data that has the potential to determine the $\mathrm{K}$ fertilizer rates in different inherent soil productivity level to reduce environmental risk and improve yield.

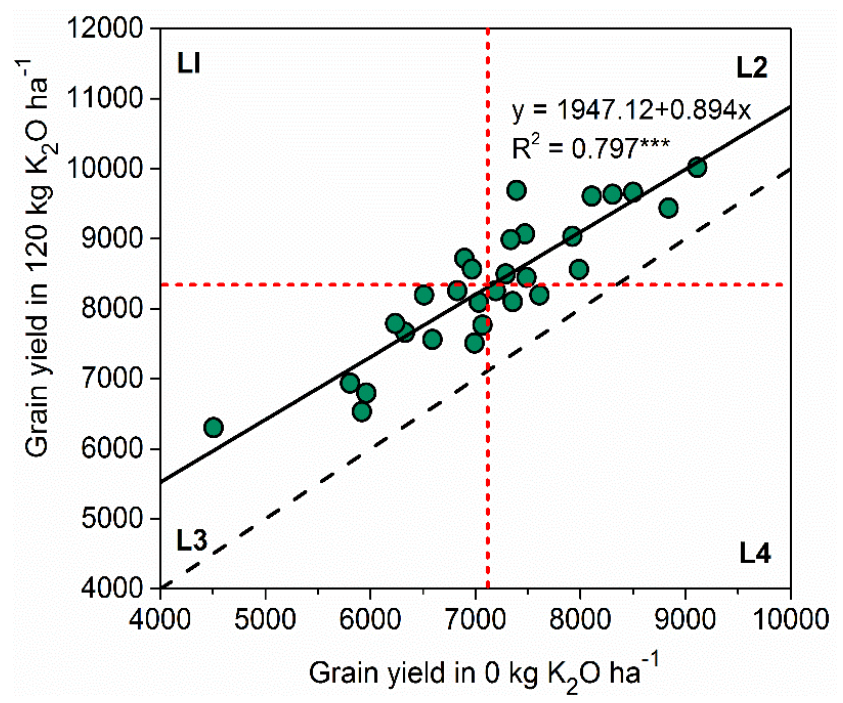

Figure 8. Relationship between rice yields without $\mathrm{K}$ application and with a $120 \mathrm{~kg} \mathrm{~K}_{2} \mathrm{O} \mathrm{ha}^{-1} \mathrm{~K}$ application rate, in different inherent soil productivity levels.

Table 3. The optimal recommended $\mathrm{K}$ rate and the corresponding theoretical yield in the different inherent soil productivity levels.

\begin{tabular}{cccc}
\hline $\begin{array}{c}\text { Different Inherent Soil } \\
\text { Productivity Levels }\end{array}$ & Item & $\begin{array}{c}\text { Optimal Recommended } \\
\text { K Rate }\end{array}$ & $\begin{array}{c}\text { The Corresponding } \\
\text { Theoretical Yield }\end{array}$ \\
\hline \multirow{2}{*}{ L1 } & Mean & 116.1 & 9966.1 \\
& Max & 113.8 & 9738.3 \\
& Min & 118.5 & 10193.8 \\
\hline \multirow{2}{*}{ L2 } & Mean & 111.2 & 10158.8 \\
& Max & 92.8 & 9161.5 \\
& Min & 129.0 & 11144.5 \\
\hline \multirow{2}{*}{ L3 } & Mean & 112.2 & 8373.2 \\
& Max & 94.8 & 7371.5 \\
& Min & 134.5 & 9604.0 \\
\hline & Mean & 111.7 & 8881.9 \\
& Max & 105.1 & 8785.1 \\
& Min & 115.4 & 8940.0 \\
\hline
\end{tabular}


The red line in the figure represents the mean grain yield rate without $\mathrm{K}$ application $\left(7155.5 \mathrm{~kg} \mathrm{ha}^{-1}\right)$ and mean rice yield in $120 \mathrm{~kg} \mathrm{~K}_{2} \mathrm{O} \mathrm{ha}^{-1}\left(8342.6 \mathrm{~kg} \mathrm{ha}^{-1}\right)$. ${ }^{* * *}$ represents significance at the 0.01 level. The 29 experimental sites were divided into four inherent soil productivity levels: L1, low yield in $0 \mathrm{~kg}$ $\mathrm{K}_{2} \mathrm{O} \mathrm{ha}^{-1}$ and high yield in $120 \mathrm{~kg} \mathrm{~K}_{2} \mathrm{O} \mathrm{ha}^{-1}$; L2, high yield in both 0 and $120 \mathrm{~kg} \mathrm{~K}_{2} \mathrm{O} \mathrm{ha}{ }^{-1}$; L3, low yield in both 0 and $120 \mathrm{~kg} \mathrm{~K}_{2} \mathrm{O} \mathrm{ha}^{-1}$; and L4, high yield in $0 \mathrm{~kg} \mathrm{~K}_{2} \mathrm{O} \mathrm{ha}^{-1}$ and low yield in $120 \mathrm{~kg} \mathrm{~K}_{2} \mathrm{O}$ $\mathrm{ha}^{-1}$.

\section{Conclusions}

More efficient use of potassium (K) fertilizer application plays an important role in improving crop productivity. The highest yield consistently achieved in the K120 treatment during the experimental period (with an average of $8342.6 \mathrm{~kg} \mathrm{ha}^{-1}$, ranged from 6305 to $10021.4 \mathrm{~kg} \mathrm{ha}^{-1}$ ) and the grain yield followed the sequence $\mathrm{K} 120>\mathrm{K} 60>\mathrm{K} 180>\mathrm{K} 0$. The highest plant $\mathrm{K}$ uptake was observed in the $\mathrm{K} 180$ treatment followed by the $\mathrm{K} 120$ and $\mathrm{K} 60$, and the same results were also observed in straw and grain $\mathrm{K}$ uptake. A remarkable correlation between biomass accumulation and plant $\mathrm{K}$ uptake was $y=-0.237 x^{2}+135.3 x+3796.2$, which has positive polynomial function. The average $F_{C} R_{K}$ was $8.11 \%, 14.29 \%$, and $7.30 \%$ in the K60, K120, and K180 treatments. Moreover, the average recommended $\mathrm{K}$ application rate for the 29 experimental sites was $112 \mathrm{~kg} \mathrm{ha}^{-1}$, and the corresponding theoretical yields of recommended $\mathrm{K}$ rate ranged from 7371.5 to 11144.5 , and with an average of $9297.5 \mathrm{~kg} \mathrm{ha}^{-1}$. Remarkably, the average recommended $\mathrm{K}$ application rates in the four inherent soil productivity levels were 116.1, 111.2, 112.2 and $111.7 \mathrm{~kg} \mathrm{ha}^{-1}$. These results could provide more reliable support for policy-makers to implement the development of strategies to guarantee sustainable rice production.

Author Contributions: Conceptualization, W.J. and X.W.; methodology, X.L. and X.W.; Data analysis, W.J., Y.X. and Z.C.; investigation, X.L. and L.Y.; Writing—Original Draft preparation, W.J.; Writing-Review and Editing, W.J.; funding acquisition, W.J. and X.L.

Funding: Supported by the Shaanxi Engineering and Technological Research Center for Conversation and Utilization of Regional Biological Resource [sxgczx-2019-08], and Specialized Research Fund for the Doctoral Program of Yan'an University [YDBK2018-51], and by the National Key Research and Development Program of China [2016YFD0200105].

Conflicts of Interest: The authors declare no conflict of interest.

\section{References}

1. Li, P.; Lu, J.; Wang, Y.; Wang, S.; Hussain, S.; Ren, T.; Cong, R.; Li, X. Nitrogen losses, use efficiency, and productivity of early rice under controlled-release urea. Agric. Ecosyst. Environ. 2018, 251, 78-87. [CrossRef]

2. Gu, J.; Jing, C.; Lu, C.; Wang, Z.; Hao, Z.; Yang, J. Grain quality changes and responses to nitrogen fertilizer of japonica rice cultivars released in the Yangtze River Basin from the 1950s to 2000s. Crop J. 2015, 3, $285-297$. [CrossRef]

3. Charles, H.; Godfray, J.; Beddington, J.R.; Crute, I.R.; Haddad, L.; Lawrence, D.; Muir, J.F.; Robinson, S.; Thomas, S.M. Food Security: The challenge of feeding 9 billion people. Science 2010, 327, 812-818.

4. Zhang, H.; Xu, M.; Shi, X.; Li, Z.; Huang, Q.; Wang, X. Rice yield, potassium uptake and apparent balance under long-term fertilization in rice-based cropping systems in southern China. Nutr. Cycl. Agroecosyst. 2010, 88, 341-349. [CrossRef]

5. Zhang, H.; Liu, H.; Hou, D.; Zhou, Y.; Liu, M.; Wang, Z.; Liu, L.; Gu, J.; Yang, J. The effect of integrative crop management on root growth and methane emission of paddy rice. Crop J. 2019, 7, 444-457. [CrossRef]

6. Sinebo, W. Yield Relationships of barleys grown in a tropical highland environment. Crop Sci. 2002, 42, 428-437. [CrossRef]

7. Li, G.; Zhang, J.; Yang, C.; Song, Y.; Zheng, C.; Wang, S.; Liu, Z. Optimal yield-related attributes of irrigated rice for high yield potential based on path analysis and stability analysis. Crop J. 2014, 2, 235-243. [CrossRef]

8. Xue, Y.; Hua, D.; Liu, L.; Wang, Z.; Yang, J.; Zhang, J. An Improved Crop Management Increases Grain Yield and Nitrogen and Water Use Efficiency in Rice. Crop Sci. 2013, 53, 271-284. [CrossRef] 
9. Zhang, H.; Yu, C.; Kong, X.; Hou, D.; Gu, J.; Liu, L.; Wang, Z.; Yang, J. Progressive integrative crop managements increase grain yield, nitrogen use efficiency and irrigation water productivity in rice. Field Crop. Res. 2018, 215, 1-11. [CrossRef]

10. Fan, M.; Shen, J.; Yuan, L.; Jiang, R.; Chen, X.; Davies, W.J.; Zhang, F. Improving crop productivity and resource use efficiency to ensure food security and environmental quality in China. J. Exp. Bot. 2012, 63, 13-24. [CrossRef]

11. Min, H.; Zhou, X.; Zou, Y. Improving nitrogen management for zero-tillage rice in China. Crop J. 2018, 6, 406-412.

12. Galloway, J.N.; Townsend, A.R.; Erisman, J.W.; Bekunda, M.; Cai, Z.C.; Freney, J.R.; Martinelli, L.A.; Seitzinger, S.P.; Sutton, M.A. Transformation of the nitrogen cycle: Recent trends, questions, and potential solutions. Science 2008, 320, 889-892. [CrossRef] [PubMed]

13. Jiang, W.T.; Liu, X.H.; Wang, Y.; Zhang, Y.; Qi, W. Responses to Potassium Application and Economic Optimum K Rate of Maize under Different Soil Indigenous K Supply. Sustainability 2018, 10, 2267. [CrossRef]

14. Guo, J.H.; Liu, X.J.; Zhang, Y.; Shen, J.L.; Han, W.X.; Zhang, W.F.; Christie, P.; Goulding, K.W.; Vitousek, P.M.; Zhang, F.S. Significant acidification in major Chinese croplands. Science 2010, 327, 1008-1010. [CrossRef]

15. Ma, Y.C.; Kong, X.W.; Yang, B.; Zhang, X.L.; Yan, X.Y.; Yang, J.C.; Xiong, Z.Q. Net global warming potential and greenhouse gas intensity of annual rice-wheat rotations with integrated soil-crop system management. Agric. Ecosyst. Environ. 2013, 164, 209-219. [CrossRef]

16. Wang, M.; Zheng, Q.; Shen, Q.; Guo, S. The Critical Role of Potassium in Plant Stress Response. Int. J. Mol. Sci. 2013, 14, 7370-7390. [CrossRef]

17. Zorb, C.; Senbayram, M.; Peiter, E. Potassium in agriculture-status and perspectives. J. Plant Physiol. 2014, 171, 656-669. [CrossRef]

18. Trivedi, K.; Kubavat, D.; Ghara, K.K.; Kumar, R.; Trivedi, H.; Anand, K.G.V.; Maiti, P.; Ghosh, A. Evaluation of Fertilizer Potential of Different K Compounds Prepared Utilizing Sea Bittern as Feed Stock. Front. Plant Sci. 2017, 8, 1541-1553. [CrossRef]

19. Cong, R.; Li, H.; Zhang, Z.; Ren, T.; Li, X.; Lu, J. Evaluate regional potassium fertilization strategy of winter oilseed rape under intensive cropping systems: Large-scale field experiment analysis. Field Crop. Res. 2016, 193, 34-42. [CrossRef]

20. He, P.; Yang, L.; Xu, X.; Zhao, S.; Chen, F.; Li, S.; Tu, S.; Jin, J.; Johnston, A.M. Temporal and spatial variation of soil available potassium in China (1990-2012). Field Crop. Res. 2015, 173, 49-56. [CrossRef]

21. Wang, X.K.; Fan, J.L.; Xing, Y.Y.; Xu, G.C.; Wang, H.D.; Deng, J.; Wang, Y.F.; Zhang, F.C.; Li, P.; Li, Z.B. The effects of mulch and nitrogen fertilizer on the soil environment of crop plants. Adv. Agron. 2019, 153, 121-173.

22. Wu, L.; Ma, W.; Zhang, C.; Wu, L.; Zhang, W.; Jiang, R.; Zhang, F.; Cui, Z.; Chen, X. Current potassium management status and grain yield response of Chinese maize to potassium application. J. Plant Nutr. Soil Sci. 2013, 176, 441-449. [CrossRef]

23. Zhang, R.X.; Liu, X.Z.; Wang, W.N.; Wang, Y.Z.; Li, H.; Zhang, Z.X.; Xu, Q. Study on the application effects of $\mathrm{N}, \mathrm{P}$, and $\mathrm{K}$ fertilizers on rice and the recommended fertilizer amount in eastern Huibei. J. Hubei Agric. Sci. 2009, 13, 35-38. (In Chinese)

24. FAO (Food and Agriculture Organization of the United Nations). FAOSTAT Database-Agricultural Production; FAO: Rome, Italy, 2012.

25. Xu, X.P.; Xie, J.G.; Hou, Y.P.; He, P.; Pampolino, M.F.; Zhao, S.C.; Zhou, W. Estimating nutrient uptake requirements for rice in China. Field Crop. Res. 2015, 180, 37-45. [CrossRef]

26. Liao, Y.L.; Lu, Y.H.; Xie, J.; Nie, J.; Yang, Z.P.; Zhou, X. Effects of Long-term application of chemical potassium fertilizer and incorporation of rice straw on potassium supplying capacity of red soil in double cropping paddy field. Acta Pedol. Sin. 2017, 54, 456-466. (In Chinese)

27. Qiu, S.; Xie, J.; Zhao, S.; Xu, X.; Hou, Y.; Wang, X.; Zhou, W.; He, P.; Johnston, A.M.; Christie, P. Long-term effects of potassium fertilization on yield, efficiency, and soil fertility status in a rain-fed maize system in northeast China. Field Crop. Res. 2014, 163,1-9. [CrossRef] 
28. Chen, Y.; Li, Y.; Hu, D.; Zhang, X.; Wen, Y.; Chen, D. Spatial distribution of potassium uptake across the cotton plant affects fiber length. Field Crop. Res. 2016, 192, 126-133. [CrossRef]

29. Chuan, L.; He, P.; Jin, J.; Li, S.; Grant, C.; Xu, X.; Qiu, S.; Zhao, S.; Zhou, W. Estimating nutrient uptake requirements for wheat in China. Field Crop. Res. 2013, 146, 96-104. [CrossRef]

(C) 2019 by the authors. Licensee MDPI, Basel, Switzerland. This article is an open access article distributed under the terms and conditions of the Creative Commons Attribution (CC BY) license (http://creativecommons.org/licenses/by/4.0/). 